\title{
AS MEDIDAS SOCIOEDUCATIVAS DO ESTATUTO DA CRIANÇA E DO ADOLESCENTE E SEUS PARÂMETROS NORMATIVOS DE APLICAÇÃO
}

\author{
Caroline Köhler Teixeira'
}

Resumo: Aborda os critérios legais para aplicação de medidas socioeducativas a adolescentes infratores. Ressalta os objetivos pedagógicos e ressocializadores da persecução socioeducativa. Perpassa pelas características de cada uma das medidas socioeducativas que integram o rol taxativo do art. 112 do Estatuto da Criança e do Adolescente. Pretende fornecer parâmetros para a eleição das medidas socioeducativas mais apropriadas em cada caso concreto, já que as normas que disciplinam o direito infracional não prefixam medidas específicas a cada um dos tipos infracionais, análogos a crimes ou contravenções penais.

Palavras-chave: Medidas socioeducativas. Parâmetros de aplicação.

\section{INTRODUÇÃO}

O Estatuto da Criança e do Adolescente, na esteira do advento da Constituição da República, acarretou uma mudança paradigmática significativa quanto ao tratamento oferecido

1 Defensora Pública do Estado de Santa Catarina - Núcleo Regional de Lages. Ex- aluna dos Módulos I, II e III da ESMESC. Especialista em Direito Público pelo Instituto de Ensino Luis Flávio Gomes (LFG) em convênio com a Universidade do Sul de Santa Catarina (UNISUL) e pela Escola Superior da Magistratura Federal do Estado de Santa Catarina (ESMAFESC) em convênio com a Universidade do Vale do Itajaí (UNIVALI). Bacharel em Direito pela Universidade Federal de Santa Catarina (UFSC). E-mail: carolinekteixeira@gmail.com 
a crianças e adolescentes, notadamente transformando-os em sujeitos de direito, garantindo-lhes seus direitos individuais específicos e ainda conferindo-lhes uma proteção diferenciada e mais abrangente, se comparada àquela inserta no Código de Menores, que por aquele foi revogado.

Contudo, apesar das profundas alterações legislativas realizadas há mais de vinte anos, grande parte dos operadores jurídicos ainda manuseiam as normas da Lei no 8.069/90 com a mentalidade formada sob a égide da legislação revogada, menos protetiva e em muitos aspectos violadora de direitos constitucionais fundamentais da pessoa em desenvolvimento.

É possível vislumbrar essa vetusta interpretação retrospectiva de forma ainda mais aguda na seara do Direito Infracional, mormente em se considerando que o Estatuto da Criança e do Adolescente não traz um sistema fechado e inflexível de critérios de aplicação de medidas socioeducativas, mas sim parâmetros gerais baseados em conceitos jurídicos indeterminados, que dependem do alvedrio do aplicador do Direito para se concretizarem.

Diante disso, este estudo pretende visitar os critérios normativos afetos à aplicação de medidas socioeducativas, destacando seu manuseio à luz dos escopos próprios da Lei $\mathrm{n}^{\circ} 8.069 / 90$, sobretudo o resgate da integridade dos direitos do adolescente que pratique ato infracional e o respeito à sua condição de pessoa em peculiar estágio de desenvolvimento.

Além disso, defende-se que, no exercício de tal mister, o magistrado privilegie a feição ressocializadora da persecução socioeducativa, deixando em segundo plano aquelas de caráter retributivo, punitivo ou sancionatório, já que estes são atributos em sua gênese vocacionados ao Direito Penal.

Para tanto, num primeiro momento, serão feitas considerações a respeito do pressuposto, da natureza e também dos escopos da persecução socioducativa.

Posteriormente, serão abordadas as medidas em espécie previstas no Estatuto da Criança e do Adolescente, apontando- 
-se suas peculiaridades, bem como as características comuns a todas elas.

Por derradeiro, a pesquisa se voltará à averiguação dos critérios normativos de aplicação de medidas socioeducativas, pelo magistrado, no momento final do procedimento de apuração de ato infracional, quando já demonstradas a materialidade e a autoria de ato análogo a crime ou contravenção penal.

\section{PRESSUPOSTO, NATUREZA E ESCOPO DA PERSECUÇÃO SOCIOEDUCATIVA}

Inicialmente, antes de adentrar no cerne da questão, referente às medidas socioeducativas previstas na lei de proteção às crianças e adolescentes, bem como aos critérios normativos que norteiam sua aplicação, é indispensável tecer algumas elucidativas explicações a respeito do pressuposto para a aplicação de medidas socioeducativas, bem como da natureza e da finalidade da persecução socioeducativa.

\section{1 - Pressuposto}

O nascimento da pretensão socioeducativa estatal se dá com a ocorrência de seu pressuposto legalmente estabelecido - a prática de ato infracional por adolescente, nos termos do art. 112 da Lei no 8.069/90: "verificada a prática de ato infracional, a autoridade competente poderá aplicar ao adolescente as seguintes medidas: (...)".

É mister, assim, ter em mente o significado daquele que é o pressuposto da persecução socioeducativa - o ato infracional praticado por adolescente, pois, se praticado por criança, não há dúvida de que a tutela é eminentemente protetiva.

Trata-se de um conceito normativo, estabelecido pelo art. 103 do Estatuto da Criança e do Adolescente: "considera-se ato infracional a conduta descrita como crime ou contravenção penal". 
Deste modo, é possível concluir que ato infracional, como pressuposto da persecução socioeducativa, é o ato praticado por adolescente análogo a alguma conduta tipificada como crime ou contravenção penal.

De fato, tanto a criança como o adolescente podem cometer ato infracional ${ }^{2}$. Contudo, por serem penalmente inimputáveis, a um e outro se aplicam medidas previstas na Lei $\mathrm{n}^{\circ}$ 8.069/903.

A diferença reside no tratamento diferenciado que recebem, pois enquanto à criança são aplicáveis apenas as medidas de proteção do art. 101, I a IX', a lei autoriza que os adolescentes suportem medidas socioeducativas previstas no art. 112, bem como algumas das medidas de proteção - somente aquelas previstas nos incisos I a VI do art. 101.

Nesse último viés, as medidas de proteção ganham contornos de medidas socioeducativas, podendo ser aplicadas, de acordo com parte considerável da doutrina e jurisprudência, cumulativamente com aquelas previstas no capítulo IV do Estatuto da Criança e do Adolescente 5 .

Contudo, o foco principal deste estudo são as medidas socioeducativas propriamente ditas e, por isso, estas serão abordadas com mais ênfase do que as medidas de proteção aplicáveis a adolescentes infratores.

Assim, se o pressuposto para a atuação da persecução socioeducativa é a prática de ato infracional por adolescente, a imposição de uma medida socioeducativa pressupõe, em regra, prova suficiente da materialidade e da autoria do ato infracional

2 Art. $2^{\circ}$ : "Considera-se criança, para os efeitos desta Lei, a pessoa até doze anos de idade incompletos, e adolescente aquela entre doze e dezoito anos de idade.

3 Art. 104. São penalmente inimputáveis os menores de dezoito anos, sujeitos às medidas previstas nesta Lei.

Parágrafo único. Para os efeitos desta Lei, deve ser considerada a idade do adolescente à data do fato.

4 Art. 105. Ao ato infracional praticado por criança corresponderão as medidas previstas no art. 101.

5 O capítulo IV é intitulado "Das medidas socioeducativas" 
praticado, nos termos do disposto no art. 114 da lei que tutela crianças e adolescentes ${ }^{6}$.

Diz-se como regra porque o Estatuto da Criança e do Adolescente, no dispositivo acima referido (in fine), permite a aplicação de medidas socioeducativas não restritivas de liberdade em sede de remissão, o que poderá ocorrer extraprocessualmente - mediante atuação do promotor de justiça, acarretando a exclusão do processo - ou no curso do deste - hipótese em que é aplicada pelo próprio magistrado, dando azo à suspensão ou à extinção do processo?

De qualquer forma, inclusive para fins de utilização de tal instituto, não se dispensa prova mínima da autoria do ato análogo a crime ou contravenção, já que sua aplicação deve levar em conta a "maior ou menor participação no ato infracional", segundo a literalidade do artigo transcrito em nota de rodapé por ocasião no parágrafo anterior.

Outra flexibilização da Lei no 8.069/90, igualmente prevista em seu art. 114, dá-se na aplicação da medida de advertência, que exige prova de existência do ato infracional e apenas indícios de autoria (COSTA, 2005, p. 84).

Ademais, cumpre salientar que as medidas socioeducativas só podem ser aplicadas por autoridade, assim entendendo-se tanto o magistrado, no bojo de ação de apuração de ato infracional (vide enunciado 108 da Súmula do Superior Tribunal

6 Art. 114. A imposição das medidas previstas nos incisos II a VI do art. 112 pressupõe a existência de provas suficientes da autoria e da materialidade da infração, ressalvada a hipótese de remissão, nos termos do art. 127.

Parágrafo único. A advertência poderá ser aplicada sempre que houver prova da materialidade e indícios suficientes da autoria.

7 Art. 126. Antes de iniciado o procedimento judicial para apuração de ato infracional, o representante do Ministério Público poderá conceder a remissão, como forma de exclusão do processo, atendendo às circunstâncias e conseqüências do fato, ao contexto social, bem como à personalidade do adolescente e sua maior ou menor participação no ato infracional.

Parágrafo único. Iniciado o procedimento, a concessão da remissão pela autoridade judiciária importará na suspensão ou extinção do processo.

Art. 127. A remissão não implica necessariamente o reconhecimento ou comprovação da responsabilidade, nem prevalece para efeito de antecedentes, podendo incluir eventualmente a aplicação de qualquer das medidas previstas em lei, exceto a colocação em regime de semi-liberdade e a internação. 
de Justiça), como o Promotor de Justiça, em sede de remissão extraprocessual (ISHIDA, 2010, p. 257-258), mas, no caso deste, apenas em relação às medidas não restritivas de liberdade.

Enfim, faz-se pertinente deixar claro que, por uma questão de isonomia e proporcionalidade, o desempenho da atividade estatal socioeducativa deve respeitar todo o arcabouço principiológico garantista do processo penal que, em verdade, funda-se em diretrizes impostas pela própria Constituição da República.

De fato, malgrado se pretenda relegar o cunho penal da persecução socioeducativa a um segundo plano, privilegiando-se os seus escopos ressocializadores, não se pode negar que tanto o Direito Infracional como o Direito Penal compartilham do arcabouço principiológico garantista de sede constitucional.

Assim, se certo distanciamento do Direito Penal outrora preconizado é premissa inafastável da boa aplicação de medidas socioeducativas, o estreitamento em razão da matriz constitucional dos princípios garantidores dos direitos dos indivíduos submetidos à persecução estatal também é, apenas neste último ponto, desejado.

É o que ensina Paulo Afonso Garrido de Paula, ao discorrer a respeito do fato gerador das medidas socioeducativas:

"Têm como fato gerador a existência reconhecida da prática de uma conduta equiparada a crime ou contravenção penal, pressupondo um sistema de apuração que contemple as garantias fundamentais e gerais insertas no art. 5o da Constituição da República, cujo 'caput' veda distinções decorrentes da idade, vem como aquelas especiais, presentes no art. 227 da mesma Carta" (PAULA, 2006, p. 34).

Nesse compasso, são inequivocamente aplicáveis à persecução socioeducativa os princípios da legalidade (ROSSATO et. al.; 2011, p. 307), do devido processo legal, da ampla defesa, 
da presunção da inocência, do juiz natural, da não auto-incriminação, da vedação da reformatio in pejus, da proibição da utilização de provas ilícitas, salvo em prol da defesa, da publicidade processual em sua relação, da fundamentação das decisões, etc. (ROSA et al, 2011, p. 212-219) e também a razoável duração do processo.

Como reflexo, em relação às medidas previstas de maneira taxativa (por força dos princípios da legalidade e da tipicidade fechada) no Estatuto da Criança e do Adolescente, pode-se dizer que não só que são aplicáveis aos inimputáveis que cometam atos infracionais, mas também que só o são diante da prática de atos penalmente tipificados como crime ou contravenção penal.

Além disso, referida verificação deve ser realiada no bojo de um procedimento adequado aos preceitos constitucionais e às previsões específicas do Estatuto da Criança e do Adolescente, como o direito de ser ouvido pessoalmente pela autoridade, de solicitar a presença dos pais e defensores a qualquer tempo ${ }^{8}$, de não ficar provisoriamente internado por mais de quarenta e cinco dias ${ }^{9}$, a judicialização da execução da medida socioeducativa, etc.

Mas não é só o sistema processual penal que pode ser utilizado, quando couber, na persecução socioeducativa (D'ANDREA, 2005, p. 85). A dogmática penal, notadamente no que se refere à estrutura do crime (COSTA, 2005, p. 74) e à prescrição da pretensão estatal - vide enunciado 338 da Súmula do Tribunal da Cidadania -, também deve ser considerada na análise do cometimento de um ato infracional por adolescente.

Vale dizer, sendo o ato infracional a conduta análoga a crime ou contravenção, todos os elementos destes devem ser

8 Art. 111. São asseguradas ao adolescente, entre outras, as seguintes garantias: I - pleno e formal conhecimento da atribuição de ato infracional, mediante citação ou meio equivalente; II - igualdade na relação processual, podendo confrontar-se com vítimas e testemunhas e produzir todas as provas necessárias à sua defesa; III - defesa técnica por advogado; IV - assistência judiciária gratuita e integral aos necessitados, na forma da lei; $V$ - direito de ser ouvido pessoalmente pela autoridade competente; VI - direito de solicitar a presença de seus pais ou responsável em qualquer fase do procedimento.

9 Art. 108. A internação, antes da sentença, pode ser determinada pelo prazo máximo de quarenta e cinco dias. 
sopesados na verificação de um ato infracional, quais sejam: a conduta dolosa ou culposa, o resultado, o nexo de causalidade, a tipicidade e a inexistência de causa de exclusão de antijuridicidade (ROSSATO et. al.; 2011, p. 307) e a culpabilidade, exceto no que se refere à imputabilidade, é claro.

Isto ocorre porque não se pode admitir que a pessoa em estágio peculiar de desenvolvimento que pratique ato análogo a um crime ou contravenção cometido por imputável seja tratado de forma mais gravosa que este (SARAIVA, 2002, p. 43). E muito menos se pode punir um adolescente quando não se puniria um adulto (SARAIVA, 2002, p. 32).

Tais premissas, uma verdadeira conquista, estão hoje expressas no art. 35, I da Lei 12.594/12: "Art. 35. A execução das medidas socioeducativas reger-se-á pelos seguintes princípios: I - legalidade, não podendo o adolescente receber tratamento mais gravoso do que o conferido ao adulto" (grifei).

Eis a justificativa também para aplicação da prescrição penal às medidas socioeducativas, sempre com os prazos reduzidos à metade, em razão do que dispõe o art. 115 do Código Penal.

Também como consectário da aplicação do aparato principiológico do processo penal, argumenta-se que as medidas socieducativas devem deixar de ser aplicadas não só nos casos previstos do art. 189 da Lei no 8.069/90 10 , mas também quando vislumbradas as hipóteses de absolvição descritas no art. 386 do Código de Processo Penal, notadamente as que contemplam o benefício da dúvida, a inexistência de prova robusta - nestes casos em decorrência do princípio da presunção de inocência e as excludentes de ilicitude e culpabilidade ${ }^{11}$.

10 Art. 189. A autoridade judiciária não aplicará qualquer medida, desde que reconheça na sentença:

I - estar provada a inexistência do fato;

II - não haver prova da existência do fato;

III - não constituir o fato ato infracional;

IV - não existir prova de ter o adolescente concorrido para o ato infracional.

11 Art. 386. O juiz absolverá o réu, mencionando a causa na parte dispositiva, desde que reconheça:

I - estar provada a inexistência do fato;

II - não haver prova da existência do fato; 
Alfim, é preciso deixar claro que, além da aplicação à persecução socioeducativa dos princípios processuais penais com ela compatíveis, o adolescente infrator ainda desfruta de outros dispositivos normativos próprios, insertos não só no Estatuto da Criança e do Adolescente, como também na Constituição da República ${ }^{12}$, os quais têm arrimo na Doutrina da Proteção Integral e tornam a tutela socioecucativa diferenciada, em respeito à especial condição da criança e do adolescente, de pessoa em estágio peculiar de desenvolvimento.

Assim, por oportuno, no tópico seguinte, ressaltar-se-á este último aspecto, abordando-se a natureza jurídica da tutela persecutória socioeducativa e sua relação com a supracitada Doutrina da Proteção Integral à Criança e ao Adolescente.

\section{2 - Natureza e escopos}

Persiste ainda, notadamente em doutrina, certa controvérsia acerca da natureza jurídica da persecução socioeducativa estatal, fundada no Estatuto da Criança e do Adolescente.

Tradicionalmente, é concebida como um Direito Penal Juvenil, com caráter nitidamente tutelar, de nuances retributivas, já que a lei anterior que tratava do tema, o Código de Menores $^{13}$, recebia, pelos aplicadores do Direito, interpretação e tratamento assemelhados ao da lei penal.

É o que advoga Wilson Donizeti Liberati:

"O Código revogado não passava de um Código Penal do

'Menor', disfarçado em sistema tutelar; suas medidas não

III - não constituir o fato infração penal;

IV - estar provado que o réu não concorreu para a infração penal;

V - não existir prova de ter o réu concorrido para a infração penal;

$\mathrm{VI}$ - existirem circunstâncias que excluam o crime ou isentem o réu de pena (arts. $\underline{20}, 21,22,23,26$ e $\S 10$ do art. 28 , todos do Código Penal), ou mesmo se houver fundada dúvida sobre sua existência;

VII - não existir prova suficiente para a condenação.

12 Assim como a concepção da menoridade penal como cláusula pétrea, nos termos dos arts. 228 e 60, $\S 4^{\circ}$, IV, da Constituição da República

13 BRASIL. Código de menores. Lei 6.697, de 10 de outubro de 1979. Código de Menores. Disponível em <http://www.planalto.gov.br>. Acesso em 21/10/2012. 
passavam de verdadeiras sanções, ou seja, penas, disfarçadas em medidas de proteção. Não relacionava nenhum direito, a não ser aquele sobre a assistência religiosa; não trazia nenhuma medida de apoio à família; tratava da situação irregular da criança e do jovem, que, na realidade, eram serem privados de seus direitos" (LIBERATI, 2006, p. 15).

Além disso, não se descura que em muitos aspectos, aquele diploma normativo era até mais gravoso que o próprio Código Penal, como no caso de ausência previsão abstrata de conduta individualizada relativa ao ato infracional, já que o magistrado poderia afirmar a presença do que a revogada lei chamava de 'desvio de conduta' (art. 2, V, do revogado Código de Menores) para aplicar uma medida ao inimputável penal (ELIAS, 2005, p. 1) em 'situação irregular', expressões demasiado genéricas para garantir um mínimo de respeito ao princípio constitucional da legalidade e de seu consectário postulado da tipicidade.

De fato, não se pode aplicar o espírito meramente sancionatório da lei penal, imputando-se responsabilidade tal qual aquela que se atribui a um adulto a uma pessoa que tenha entre doze e dezoito anos incompletos (LIBERATI, 2006, p. 70-71), legalmente inimputável.

Hodiernamente, sobretudo com o encampamento da Doutrina da Proteção Integral pela Constituição da República e, por conseguinte, pelo Estatuto da Criança e do Adolescente (SARAIVA, 2002, p. 13), agiganta-se a corrente que concebe o Direito da Criança e do Adolescente, notadamente quanto à apuração de ato infracional e aplicação de medidas socioeducativas, como um microssistema suis generis, com institutos, objetivos e princípios próprios.

A mudança de paradigma, que teve como ponto de virada o advento da Constituição da República, é explicitada com propriedade por Alexandre Morais da Rosa e Ana Christina Brito Lopes: 
"Insista-se: o que se deve destacar é que houve uma transição marcada pela reforma legislativa a partir da Constituição da República, que culminou com a revogação do Código de Menores, uma migração do paradigma positivista-discricionário para o humanitário. A mudança orientou-se por um viés de interesse comum a quais quer povos: liberdades e garantias, que foi conseqüência da evolução do século XX do Direito Internacional dos Direitos Humanos. Nesta esteira, inúmeros dispositivos, textos, declarações, instrumentos de validade jurídica na defesa e proteção internacional dos Direitos Humanos foram aprovados. Para tanto, o desenvolvimento de estudos da Criminologia Crítica e da Vitimologia instrumentalizaram e influenciaram na produção internacional, refletindo e influenciando na construção da reforma legislativa nacional, em especial, no âmbito da proteção jurídica de crianças e adolescentes, configurando-se a Proteção Integral o marco filosófico que reuniria ações de proteção e garantia dos direitos humanos das crianças e adolescentes" (ROSA et al, 2011, p. XXXI).

A tendência em minimizar as características punitivas do Direito Infracional não se limita à seara doutrinária. De fato, o Superior Tribunal de Justiça já se pronunciou na mesma ótica:

“1. Tratando-se de menor inimputável, não existe pretensão punitiva estatal propriamente, mas apenas pretensão educativa, que, na verdade, é dever não só do Estado, mas da família, da comunidade e da sociedade em geral, conforme disposto expressamente na legislação de regência (Lei 8.069/90, art. 4º ) na Constituição Federal (art. 227).

2. De fato, é nesse contexto que se deve enxergar o efeito primordial das medidas socioeducativas, mesmo que apresentem, eventualmente, características expiató- 
rias (efeito secundário), pois o indiscutível e indispensável caráter pedagógico é que justifica a aplicação das aludidas medidas, da forma como previstas na legislação especial (Lei 8.069/90, arts. 112 a 125), que se destinam essencialmente à formação e reeducação do adolescente infrator, também considerado como pessoa em desenvolvimento (Lei 8.069/90, art. 6), sujeito à proteção integral (Lei 8.069/90, art. 1\%), por critério simplesmente etário (Lei 8.069/90, art. 20, caput). (...)” (STJ, 5ª Turma, HC 155.514/SP, j. em 15-06-2010).

Assim, apesar de não se poder negar algum fito punitivo no exercício da persecução socioeducativa, já que ele é amplamente reconhecido em doutrina e jurisprudência, é importante destacar que, a esse microssistema que tutela crianças e adolescentes, aplicam-se, na seara do Direito Infracional, as garantias que são genuinamente constitucionais, mas de vocação penal e processual penal, que devem ser aplicadas à luz da premissa da autonomia do Direito Infracional, cujos escopos pedagógicos se sobrepõem aos meramente expiatórios (ROSA et al, 2011, p. XXXII e XXXIII).

Com efeito, nos casos em que o adolescente comete infrações análogas a tipos penais, não se pode aplicar uma medida socioeducativa sem a observância da plenitude das garantias processuais postas à sua disposição (art. 112 do ECA)" (ELIAS, 2005, p. 2).

Tudo isso é consectário do arcabouço teórico construído pela Doutrina da Proteção Integral, descrita por João Batista Costa Saraiva nos seguintes termos:

"Esta Escola, que dirige e orienta o texto do Estatuto da Criança e do Adolescente, parte do pressuposto de que todos os direitos da criança e do adolescente devem ser reconhecidos. A Doutrina da Proteção Integral, que tem por norte a Convenção das Nações Unidas para o Direito das Crianças, estabelece que estes direitos se constituem 
em direitos especiais e específicos, pela condição que ostentam de pessoas em desenvolvimento. Desta forma, as lei internas e o sistema jurídico dos países que a adotam devem garantir a satisfação de todas as necessidades das pessoas até dezoito anos, não incluindo apenas o aspecto penal do ato praticado pela ou contra a criança, mas o seu direito à vida, à saúde, à educação, à convivência familiar e comunitária, ao lazer, à profissionalização, à liberdade, entre outros" (SARAIVA, 2002, p. 14-15).

Mais à frente, o insigne autor complementa, ao comentar a mudança paradigmática proporcionada pelo Estatuto da Criança e do Adolescente, com bases na Teoria da Proteção Integral:

"Do ponto de vista das garantias penais, processuais e de execução do sistema da justiça da infância e da juventude para jovens em conflito com a Lei, autores de condutas infracionais, poder-se-ia, preliminarmente, afirmar, como aspecto primordial, que o Estatuto da Criança e do Adolescente trouxe estes agentes da condição de objeto do processo, como os tratava o anterior regime, para o status de sujeitos do processo, conseqüentemente detentores de direitos e obrigações próprios do exercício da cidadania plena, observada sua peculiar condição de pessoa em desenvolvimento (um dos postulados da ordem legal decorrente do ECA), cumprindo um dos princípios fundamentais da Constituição Federal Brasileira, que estabelece em seu art. 1\%, inc. III, como fundamento da República, a Dignidade da Pessoa Humana" (SARAIVA, 2002, p. 18-19).

O insigne doutrinador repetidamente citado, dada sua importância como teórico precursor do Direito Penal Juvenil no Brasil, de fato reconhece as conotações retributiva e repressiva da persecução socioeducativa estatal como decorrentes do próprio sistema legal que o fundamenta: 
"Não se pode ignorar que o Estatuto da Criança e do Adolescente instituiu no Brasil um sistema de Direito Penal Juvenil. Estabelece um mecanismo de sancionamento, de caráter pedagógico em sua concepção e conteúdo, mas evidentemente retributivo em sua forma, articulado sob o fundamento do garantismo penal e de todos os princípios norteadores do sistema penal Enquanto instrumento de cidadania, fundado nos princípios do Direito Penal Mínimo, até porque inegável que tem igualmente um caráter de defesa social.

Quando se faz tal afirmativa, não se está a inventar um Direito Penal Juvenil. Tal está ínsito ao sistema do Estatuto da Criança e do Adolescente, resultante da Convenção das Nações Unidas de Direitos da Criança e do conjunto desta normativa (Regras de Benjing, etc.) e seu aclaramento decorre de uma efetiva operação hermenêutica, incorporando as conquistas do garantismo penal e a condição de cidadania que se reconhece no adolescente em conflito com a Lei" (SARAIVA, acesso em 15-12-2012).

Nesse compasso, diz-se que a persecução socioeducativa - aqui se referindo ao Direito Infracional -, sedimentada no Estatuto da Criança e do Adolescente, com os olhos voltados para a condição peculiar da pessoa em desenvolvimento, à luz da Teoria da Proteção Integral, desfruta de autonomia legislativa e jurisdicional, com natureza jurídica própria, com nuances repressivas e retributivas, mas, sobretudo, pedagógicas e ressocializadoras.

Trata-se, em verdade, de uma tutela jurídica diferenciada, com principiologia exclusiva atenta à peculiaridade e importância dos interesses gestados pelo Direito da Criança e do Adolescente, consoante sustenta Paulo Afonso Garrido de Paula:

"O fundamento objetivo de uma tutela jurisdicional diferenciada para a criança e o adolescente reside, portanto, na 
existência de um microssistema disciplinador de relações jurídicas especiais e no trato da forma de distribuição da justiça, distinta, ao menos em parte, daquela que usualmente prevista na codificação geral" (PAULA, 2006, p. 82).

Em relação ao 'trato da forma de distribuição da justiça', o autor ressalta os princípios da prioridade absoluta e do respeito à condição peculiar de pessoa em processo de desenvolvimento como instrumentos de garantia, fiel ao fito específico do Estatuto no sentido da preservação do desenvolvimento saudável e da integridade de crianças e adolescentes (PAULA, 2006, p. 86).

Ana Paula Motta Costa também defende que a Lei ${ }^{\circ}$ 8.069/90 prevê uma estirpe especial de Direito Penal, o Direito Penal Juvenil:

"Aos adolescentes não se pode imputar (atribuir) responsabilidade frente à legislação penal comum. Todavia, pode-se-lhes atribuir responsabilidade com base nas normas do Estatuto próprio, pois respondem pelos delitos que praticam, submetendo-se a medidas socioeducativas de caráter penal especial. Tal caráter justifica-se especialmente porque as referidas medidas não impostas aos sujeitos, ao mesmo tempo em que decorrem da prática de atos infracionais, ou crimes tipificados na lei penal, e, ainda, é indiscutível seu caráter aflitivo, especialmente tratando-se da privação de liberdade" (COSTA, 2005, p. 79).

Contudo, em posição contrária, escorando-se na autonomia e na natureza jurídica suis generis do Direito Infracional, há quem defenda que referida seara da Ciência Jurídica desfrute apenas de objetivos essencialmente pedagógicos e ressocializadores (CARRIDE, 2006, p. 359), passando ao largo de seu âmbito qualquer escopo puramente punitivo, sancionatório ou retributivo.

Olympio Sotto Maior reforça essa negação de objetivos punitivos relacionados à aplicação de medidas socioeducativas, 
rechaçando a concepção penalista da persecução socioeducativa:

"para o adolescente autor de ato infracional a proposta é de que, no contexto da proteção integral, receba ele medidas sócio-educativas (portanto, não punitivas), tendentes a interferir no seu processo de desenvolvimento objetivando melhor compreensão da realidade e efetiva integração social” (SOTTO MAIOR, 2010, p. 536).

José Jacob Valente faz-lhe coro:

"Ora, é incontestável que a finalidade primordial existente na imposição de qualquer medida ao adolescente é a busca de sua reabilitação. Não tendo alcançado, ainda, plena capacidade de responder criminalmente por seus atos, almeja-se que ingresse na maioridade penal recuperado" (VALENTE, 2005, p. 19).

Em Santa Catarina há também forte defensora da ideia do direito socioeducativo exclusivamente protetivo. Está-se falando de Josiane Rose Petry Veronese:

"Nesse universo diferenciado, entendemos que a Lei n. 8.069/90 efetivamente não contempla a medida sócio-educativa como uma sanção penal. Chama atenção o fato de que no art. 100 há a evidência de algo inovador: "Na aplicação das medidas, levar-se-ão em conta as necessidades pedagógicas, preferindo-se aquelas que visem o fortalecimento dos vínculos familiares e comunitários". Os artigos 119, II; 120, § 1; 123, § único, de igual modo ratificam a importância das atividades pedagógicas, as quais são obrigatórias, mesmo nas internações provisórias, pois o que se pretende é sempre o resgate desta pessoa humana, inimputável penalmente, que, no entanto, transgrediu normas. O Estatuto acredita que a melhor forma de intervir nesse adolescente em conflito com a lei é incidir 
positivamente na sua formação, servindo-se, para tanto, do processo pedagógico, como um mecanismo efetivo, que possibilite o convívio cidadão desse adolescente autor de ato infracional em sua comunidade. Pretendem, pois, tais medidas, educar para a vida social" (VERONESE, acesso em 15-12-12).

Porém, apesar dos fortes argumentos negatórios, não se pode olvidar a existência dos fitos retributivos do Direito Infracional, inclusive como decorrentes da própria legalidade do Estatuto da Criança e do Adolescente, consoante se verificou quando da exposição da brilhante doutrina de João Batista Costa Saraiva.

Mesmo assim, quando da aplicação de medidas socioeducativas, tais escopos de natureza penal devem ser balizados com os objetivos ressocializadores, protetivos e pedagógicos do Direito Penal Juvenil, já que se sedimenta na Doutrina da Proteção Integral.

Nesse sentido, registra-se a recente publicação da Lei ${ }^{\circ}$ 12.594/12 reafirma os fins ressocializadores das medidas socioeducativas, procurando conscientizar o adolescente quanto aos atos legalmente indesejados que pratique e reconduzi-lo a um meio circundante em que seus direitos fundamentais sejam preservados:

"Art. 1o Esta Lei institui o Sistema Nacional de Atendimento Socioeducativo (Sinase) e regulamenta a execução das medidas destinadas a adolescente que pratique ato infracional.

(...) § 20 Entendem-se por medidas socioeducativas as previstas no art. 112 da Lei no 8.069, de 13 de julho de 1990 (Estatuto da Criança e do Adolescente), as quais têm por objetivos:

I - a responsabilização do adolescente quanto às consequências lesivas do ato infracional, sempre que possível incentivando a sua reparação; 
II - a integração social do adolescente e a garantia de seus direitos individuais e sociais, por meio do cumprimento de seu plano individual de atendimento; e

III - a desaprovação da conduta infracional, efetivando as disposições da sentença como parâmetro máximo de privação de liberdade ou restrição de direitos, observados os limites previstos em lei”.

O mesmo diploma normativo, porém, reconhece também as nuances punitivas do Direito Infracional quando, em seu art. 35, IV e V, fala em "proporcionalidade em relação à ofensa cometida" e "brevidade da medida em resposta ao ato cometido como princípios para a execução das medidas socioeducativas.

Enfim, o que aqui se argumenta é que se o adolescente comete ato infracional, é porque não se lhe está proporcionando ambiente apto ao seu sadio desenvolvimento como sujeito de direito, e é justamente a reinserção do adolescente em contexto familiar e social apropriado que deve ser focado na aplicação de medidas socioeducativas, consoante se averiguará no quarto item deste estudo, o que será mais eficazmente alcançado se forem privilegiados os escopos pedagógicos e ressocializadores do Direito Penal Juvenil.

Antes, todavia, é necessário imergir em algumas noções relativas às medidas socioeducativas taxativamente previstas pelo Estatuto da Criança e do Adolescente.

\section{AS MEDIDAS SOCIOEDUCATIVAS EM ESPÉCIE}

Segundo a lição de Luciano Alves Rossato, Paulo Eduardo Lépore e Rogério Sanches Cunha, "medida socioeducativa pode ser definida como uma medida jurídica aplicada em procedimento adequado ao adolescente autor de ato infracional" (ROSSATO et. al.; 2011, p. 330).

Em outros dizeres, pode-se conceituar medida socioecucativa como uma das providências elencadas nos arts. $112 \mathrm{e}$ 101, I a VI, da Lei no 8.069/90 passíveis de serem aplicadas ao 
adolescente diante da constatação de conduta análoga a crime ou contravenção penal em um processo judicial de apuração de prática, nos termos dos arts. 171 a 190 do Estatuto da Criança e do Adolescente.

Não se olvida, contudo, que as medidas socioeducativas cumpridas em meio aberto - todas, exceto a semilberdade e a internação - podem ter lugar na remissão extraprocessual aplicada pelo Promotor de Justiça (SOTTO MAIOR, 2010, p. 534), quando, inclusive, não há necessidade de prova plena de materialidade e autoria.

$\mathrm{O}$ rol de medidas socioeducativas elencadas no Estatuto da Criança e do Adolescente é taxativo. Nesse viés, explicita Olympio Sotto Maior: "como se trata de rol taxativo (e não simplesmente exemplificativo), é vedada a imposição de medidas diversas daquelas enunciadas no artigo em tela" (SOTTO MAIOR, 2010, p. 534).

Consoante dito anteriormente, as medidas socioeducativas previstas no art. 112 da Lei no 8.069/90 são aplicáveis apenas a adolescentes infratores, nunca a crianças. Todavia, algumas das medidas de proteção - aquelas previstas no art. 101, I a VI - também podem ter função de medidas socioeducativas, sendo também aplicáveis a adolescentes que cometam ato infracional, nos termos do que dispõe o art. 112, VI, da mencionada lei extravagante (SARAIVA, 2002, p. 29).

Além disso, quando cabível e pertinente, é admitida, pela doutrina e jurisprudência majoritárias, como consectário do que dispõe o art. 112, VI do Estatuto da Criança e do Adolescente, a aplicação cumulativa de medidas socioeducativas, notadamente as não-privativas de liberdade, com protetivas.

Assim sendo, serão tecidos comentários pertinentes não só quanto às medidas socieducativas propriamente ditas advertência, obrigação de reparar o dano, prestação de serviços à comunidade, liberdade assistida, inserção em regime de semiliberdade e internação em estabelecimento educacional -, mas também, só que de maneira muito mais sucinta, acerca das 
medidas de proteção passíveis de serem aplicadas ao adolescente infrator - encaminhamento aos pais ou responsável, mediante termo de responsabilidade, orientação, apoio e acompanhamento temporários, matrícula e freqüência obrigatórias em estabelecimento oficial de ensino fundamental, inclusão em programa comunitário ou oficial de auxílio à família, à criança e ao adolescente, requisição de tratamento médico, psicológico ou psiquiátrico, em regime hospitalar ou ambulatorial, e inclusão em programa oficial ou comunitário de auxílio, orientação e tratamento a alcoólatras e toxicômanos.

\subsection{Advertência}

A advertência é a mais branda das medidas socioeducativas previstas pelo Estatuto da Criança e do Adolescente e, justamente por isso, segundo a dicção de seu art. 114, parágrafo único, é a única passível de ser aplicada com base em prova da materialidade do ato infracional aliada a apenas indícios de autoria, já que as demais exigem prova plena tanto da existência como da autoria da infração.

Salutar repisar a ressalva de que as medidas socioeducativas aplicadas em sede de remissão - todas, exceto semiliberdade e internação - não precisam preencher tais requisitos, notadamente porque a aplicação do mencionado instituto não tem o condão de implicar reconhecimento da infração ou comprovação de responsabilidade, nos termos do art. 127 da Lei $\mathrm{n}^{\circ} 8.069 / 90$.

A lei de proteção a crianças e adolescentes, em seu art. 115, conceitua a advertência como a admoestação verbal do adolescente.

A respeito da conceituação legal, comenta Miguel Moacyr Alves de Lima:

“O termo 'advertência' deriva do latim advertentiva e significa o mesmo que admoestação, observação, aviso, adversão, ato de advertir. 
De todos os significados que o termo assume na linguagem natural, o Estatuto da Criança e do Adolescente captou o de 'admoestação', 'repreensão', 'censura', acentuando a finalidade pedagógica” (LIMA, 2010, p. 552-553).

A medida de advertência, ao ser aplicada, esgota-se em si mesma. Isto porque, realizada a admoestação verbal, será lavrado termo nesse sentido, restando desnecessário acompanhamento posterior do adolescente (ROSSATO et. al.; 2011, p. 334).

$\mathrm{Na}$ aplicação da medida, deverá ser feita a leitura do ato cometido, com a repreensão verbal do adolescente e ainda tomando-se o comprometimento deste no sentido de que a situação não se repetirá (ISHIDA, 2010, p. 229).

É comumente aplicada a infrações leves, cujas conseqüências não sejam muito nocivas, bem como a adolescentes que não registrem atos infracionais pretéritos: "Por fim, observamos que a advertência, na modalidade de medida sócio-educativa, deve se destinar, via de regra, a adolescentes que não registrem antecedentes infracionais e para os casos de infrações leves, seja quanto à sua natureza, seja quanto às suas conseqüências" (LIMA, 2010, p. 558).

Válter Kenji Ishida compartilha da mesma premissa: "assim, os atos infracionais como de adolescente que cometa, pela primeira vez, lesões leves em outro ou vias de fato, podem levar à aplicação desta medida” (ISHIDA, 2010, p. 229).

\subsection{Obrigação de reparar o dano}

A aplicação da medida socioeducativa em comento é afeta aos atos infracionais que ostentem reflexos patrimoniais, implicando restituição da coisa, no ressarcimento do dano ou na compensação da vítima, salvo quando houver manifesta impossibilidade de fazê-lo, sendo então substituída por outra que a autoridade julgar adequada (art. 116 e seu parágrafo único do ECA). 
A imposição da medida socioeducativa de reparação do dano, bem como das medidas que serão analisadas nos tópicos seguintes, reclama comprovação da autoria e da materialidade da infração (sempre ressalvada a hipótese de remissão, onde a prova da autoria é relativizada). Além disso, seu gerenciamento, assim como o da advertência, é feito pelo próprio Poder Judiciário (ROSSATO et. al.; 2011, p. 335).

Esclarece-se, por oportuno, que a reparação do dano não tem vocação de ser aplicada apenas às infrações contra o patrimônio, mas sim a todas aquelas em que haja algum reflexo patrimonial e, ainda, quando puder ser feita a compensação pecuniária da vítima. Nesse viés, oportuna a lição de Miguel Moacyr Alves Lima:

"A lei cuida da hipótese de ato infracional com reflexos patrimoniais. Não se restringe a prever a medida somente para os casos de atos infracionais que infrinjam diretamente os direitos de posse e propriedade, ou contra o patrimônio (...). Para afirmarmos esse entendimento, consideramos o fato de que o nosso sistema jurídico prevê a 'satisfação do dano lato sensu' para ilícitos dirigidos diretamente contra o patrimônio, para aquelas situações em que o dano à esfera patrimonial ocorre por via indireta e, por fim, para as hipóteses de dano meramente moral (arts. 1.537 a 1.553 do CC). No primeiro caso, temos a restitutio in integrum (restituição plena), forma mais singela de satisfação, que ocorre quando houver privação, por subtração, usurpação ou esbulho, de um bem corpóreo (ex.: furto, apropriação indébita) cuja integridade tenha subsistido. Sendo impossível a restituição, em vista de deterioração ou impossibilidade na recuperação da coisa, incide o ressarcimento, que, nos termos da lei civil, deve ser o mais completo possível (dano emergente, lucros cessantes, etc.). Em terceiro lugar, cabe ainda o ressarcimento quando o prejuízo é reflexo ou indireto sobre o patrimônio da vítima (ex.: o fato de alguém, pela dor decorrente de uma injúria 
grave, deixar de cumprir uma tarefa ou atividade que lhe proporcionaria vantagem econômica, como a participação em um conclave cultural, artístico ou esportivo mediante pagamento)" (LIMA, 2010, p. 561-562).

Enfim, Valter Kenji Ishida salienta ser necessário que a medida em tela tenha aptidão para "despertar no adolescente o senso de responsabilidade social e economia em face do bem alheio. A medida deve buscar a reparação do dano causado à vítima tendo sempre em vista a orientação educativa a que se presta" (ISHIDA, 2010, p. 230).

\subsection{Prestação de serviços à comunidade}

A prestação de serviços à comunidade está disciplinada no art. 117 do Estatuto da Criança e do Adolescente e implica a realização de "tarefas gratuitas de interesse geral" a serem desempenhadas em entidades assistenciais, escolas, hospitais, programas comunitários e governamentais, etc.

Sua duração temporária máxima é de seis meses, e as tarefas devem ser cumpridas em jornada máxima de oito horas por semana, optando-se por dias e horários que não acarretem prejuízo à frequência escolar ou jornada de trabalho do adolescente.

Para sua aplicação, exige-se a constatação da materialidade e da autoria do ato infracional, à exceção dos casos de remissão. Além disso, sua execução pressupõe abertura de processo de execução de medida (ROSSATO et. al.; 2011, p. 335-336).

Roberto Bergalli explica a relevância da aplicação da medida para desenvolver em adolescentes infratores um senso ético, despertando o sentimento de solidariedade comunitária:

"Nesse caso, a submissão de um adolescente a 'prestação de serviços à comunidade' tem um sentido altamente educativo, particularmente orientado a obrigar o adolescente a tomar consciência dos valores que supõem a soli- 
dariedade social praticada em seus níveis mais expressivos. Assistir aos desvalidos, aos enfermos, aos educandos (atividades que devem ser prestadas em 'atividades essenciais, hospitais, escolas e outros estabelecimentos congêneres') é tarefa que impõe a confrontação com o alter coletivo, de modo que possa demonstrar-se uma confiança recíproca que, por sua vez, está presente em todos os códigos de ética comunitária, como herança dos decálogos religiosos” (BERGALLI, 2010, p. 567).

\subsection{Liberdade assistida}

A medida socioeducativa em comento consiste num acompanhamento da vida familiar e social do adolescente, aliado à sua orientação e eventual auxílio. $\mathrm{O}$ reeducando permanece junto de sua família, mas deve comparecer à entidade de atendimento periodicamente, procedendo a entrevistas com o setor técnico (ISHIDA, 2010, p. 235).

Não só é uma faculdade prevista na Lei n 8.069/90, como também é salutar que seja nomeado ao reeducando um orientador que fique responsável por promover socialmente o adolescente e sua família, supervisionar sua frequência e seu aproveitamento escolar, bem como diligenciar para sua profissionalização e inserção no mercado de trabalho, apresentando relatório do caso (art. 119).

Olympio Sotto Maior salienta os benefícios da aplicação da medida de liberdade assistida:

"O acompanhamento, auxílio e orientação, a promoção social do adolescente e de sua família, bem como a inserção no sistema educacional e do mercado de trabalho, certamente importarão o estabelecimento de projeto de vida capaz de produzir ruptura com a prática de delitos, reforçados que restarão os vínculos entre adolescente, seu grupo de convivência e a comunidade" (SOTTO MAIOR, 2010, p. 536). 
A liberdade assistida é corriqueiramente aplicada de forma cumulativa com a de prestação de serviços à comunidade, já que a doutrina advoga ser salutar a conjugação dos efeitos pedagógicos de ambas, por se complementarem:

"A medida de PSC, entre outras vantagens, oferece ao adolescente seu sentido de contribuição comunitária, oportuniza-lhe desenvolver aptidões para o trabalho e lhe impõe disciplina. A LA, embora mais ampla medida, reserva-se para uma orientação de maior espectro, e a cumulação entre estar duas muitas vezes oportuniza uma maior completude no atendimento que se propõe" (SARAIVA, 2002, p. 100).

Deve ser aplicada por no mínimo seis meses, reavaliando-se a necessidade de prorrogação do acompanhamento no próprio processo de execução da medida, até porque, durante seu curso, pode, a qualquer tempo, ser prorrogada, revogada ou substituída por outra medida, desde que ouvidos o orientador, o Ministério Público e o defensor (art. 118, § 20) ${ }^{14}$.

Por derradeiro, há quem indique como prazo máximo, por analogia à disciplina da medida socioeducativa de internação, o período de três anos ou, antes disso, quando o adolescente completar vinte e um anos (art. 121, $\S \S 3^{\circ}$ e 5०) (ROSSATO et. al.; 2011, p. 338).

\subsection{Semiliberdade}

A semiliberdade é uma das duas - a outra é a internação, abordada no tópico seguinte - medidas restritivas de liberdade previstas na lei de proteção às crianças e aos adolescentes. Justamente em razão de sua natureza restritiva ao direito de ir e vir é que não podem ser aplicadas em sede de remissão (art. 127, parte final), exigindo ainda a constatação de materialidade e autoria plenas, por sentença.

14 Recomenda-se a leitura dos arts. 13 e 14 da Lei 12.594/12 
Na prática, consiste no recolhimento noturno do adolescente (assemelhando-se, assim, ao regime penal semiaberto) (ISHIDA, 2010, p. 239). Admite-se a realização de atividades externas, prescindindo-se de autorização judicial para tanto (art. 120).

Pode a semiliberdade ser aplicada desde o início ou então utilizada como forma de transição da internação para o meio aberto. $^{15}$

Trata-se de medida sem prazo mínimo determinado (art. $120, \S 2 \circ$ ). Contudo, à semelhança da internação, não deve exceder três anos e nem ir além do aniversário de vinte e um anos do adolescente (art. 121, §§ $3^{\circ}$ e $5^{\circ}$ ).

Isso porque, assim como a internação, submete-se aos princípios da brevidade (menor duração possível, imprescindível à ressocialização), excepcionalidade (utilização apenas em casos extraordinários - incisos do art. 122 do ECA) (ROSSATO et. al.; 2011, p. 339) e respeito à condição peculiar de pessoa em desenvolvimento (art. $121 \mathrm{c} / \mathrm{c}$ art. 120, § $2^{\circ}$, parte final).

O Estatuto da Criança e do Adolescente traz como obrigatórios, no cumprimento da medida, a escolarização e a profissionalização (art. 120, § 1\%).

Enfim, cumpre salientar que, por força do disposto no art. $120, \S 2^{\circ}$, parte final, aplicam-se à semiliberdade as disposições atinentes à internação, o que permite concluir, numa interpretação mais favorável ao adolescente, que quaisquer dessas duas medidas restritivas de liberdade só podem ser aplicadas diante de uma das hipóteses elencadas nos incisos do art. 122 da Lei $\mathrm{n}^{\circ} 8.069 / 90$, examinadas no item a seguir (BARATTA, 2010, p. 578).

\subsection{Internação}

A mais cerceadora da liberdade pessoal dentre todas as medidas previstas no Estatuto da Criança e do Adolescente

15 Recomenda-se a leitura do art. 15 da Lei 12.594/12. 
submete-se aos princípios da brevidade, da excepcionalidade e do respeito à condição peculiar de pessoa em desenvolvimento (art. 122, caput).

Quanto à abrangência de tais princípios, Valter Ishida esclarece que a brevidade implica a conclusão de que a medida deve perdurar apenas o necessário à readaptação do adolescente ao convívio social, limitando-se, assim, a três anos ou à ocasião em que o reeducando completa vinte e um anos; a excepcionalidade significa que a internação só tem lugar quando as demais medidas mostrarem-se ineficazes; e, enfim, o respeito à condição peculiar de pessoa em desenvolvimento reclama a manutenção das condições gerais para o desenvolvimento do adolescente, "garantindo seu ensino e profissionalização" (ISHIDA, 2010, p. 240-241).

Apesar de sua duração máxima ter sido limitada a três anos (art. 121, § 30) ou três meses (quando aplicada por força de reiteração de descumprimento injustificado de medida anteriormente imposta - art. 122, III c/c § 1o) ou, em qualquer caso, à ocasião do $21^{\circ}$ aniversário do indivíduo, quando se dará a liberação compulsória ou transferência para semiliberdade ou liberdade assistida (art. 121, § 4\%), a internação não tem prazo determinado, devendo ser reavaliada sua pertinência no máximo a cada seis meses (art. 121, § 20). ${ }^{16}$

Cumpre ressaltar que a liberação compulsória do adolescente ou sua transferência para a semiliberdade ou liberdade assistida requer manifestação prévia do representante do Ministério Público e autorização judicial, consoante dispõe o art. 121, $\S 4^{\circ}$, da Lei no 8.069/90.

A internação diferencia-se da semiliberdade, em síntese, pelo grau de restrição da liberdade do adolescente e também porque nesta as atividades externas constituem a regra, só podendo ser proibidas por ordem judicial fundamentada, enquanto na medida de internação "será permitida a realização de atividades externas, a critério da equipe técnica da entidade,

16 Recomenda-se a leitura do art. 15 da Lei 12.594/12. 
salvo expressa determinação judicial em contrário" (art. 121, § $1^{\circ}$ ), que pode ser revista a qualquer tempo (art. 121, § $7^{\circ}$ ).

Além disso, na internação são obrigatórias atividades pedagógicas (art. 123, parágrafo único).

À luz do postulado da excepcionalidade, a internação, como medida socioeducativa, é passível de ser aplicada somente frente a atos infracionais perpetrados com grave ameaça ou violência à pessoa (art. 122, I), por reiteração de infrações graves (art. 122, II) ou por descumprimento reiterado e injustificado de medida imposta anteriormente (art. 122, III). Neste último caso, repisa-se, com duração máxima de três meses.

Olympio Sotto Maior explica com propriedade as razões da excepcionalidade da medida de internação:

“(...) a internação é a medida sócio-educativa com as piores condições para produzir resultados positivos. Com efeito, a partir da segregação e da inexistência de projeto de vida, os adolescentes internados acabam ainda mais distantes da possibilidade de um desenvolvimento sadio. Privados de liberdade, convivendo em ambientes, de regra, promíscuos e aprendendo as normas próprias do grupos marginais (especialmente no que tange a responder com violência aos conflitos do cotidiano), a probabilidade (quase absoluta) é de que os adolescentes acabem absorvendo a chamada identidade do infrator, passando a se reconhecerem, sim, como de má índole, natureza perversa, alta periculosidade, enfim, como pessoas cuja história de vida, passada e futura, resta indestrutivelmente ligada à delinqüência (os irrecuperáveis, como dizem eles). Desta forma, quando do desinternamento, certamente estaremos diante de cidadãos com categoria piorada, ainda mais predispostos a condutas violentas e anti-sociais. Daí a importância de se observar atentamente as novas regras legais referentes à internação, especialmente aquelas que dizem respeito à excepcionalidade da medida, sua brevi- 
dade e, a todo o tempo, o respeito à condição peculiar de pessoa em desenvolvimento (de ressaltar também o novo elenco de direitos pertinentes ao adolescente internado, conforme disposição do art. 124 do ECA)" (SOTTO MAIOR, 2010, p. 536-537).

Assim, são três as excepcionais hipóteses que autorizam a adoção da internação, bem como a de semiliberdade, relegando-se ao julgador a tarefa de avaliar, à luz das nuances do caso concreto, qual dentre as duas é a mais adequada.

A primeira fattispecie - atos infracionais praticados mediante violência ou grave ameaça contra a pessoa - deve ser interpretada em favor da pessoa em condição peculiar de desenvolvimento, não se permitindo concluir que a letra da lei imponha a aplicação obrigatória de uma das medidas restritivas de liberdade - internação ou semiliberdade - sempre que o adolescente praticar ato infracional com violência ou grave ameaça contra a pessoa.

Em verdade, é mais razoável concluir que o comando legal abordado implica, ao revés, a proibição de aplicação das medidas restritivas de liberdade a atos análogos a crimes ou contravenções que não contenham os elementos nucleares típicos 'violência' ou 'grave ameaça', salvo enquadramento em um dos dois outros incisos do art. 122.

Compartilham de tal premissa Luciano Alves Rossato, Paulo Eduardo Lépore e Rogério Sanches Cunha ao afirmarem que "se o tipo penal revelar que o fato foi praticado mediante violência ou grave ameaça à pessoa, então, a internação estará abstratamente autorizada, desde que presente a necessidade pedagógica" (ROSSATO et. al.; 2011, p. 344).

Ademais, no espírito do que aqui se defende, foi recentemente aprovado o enunciado de número 492 da súmula do Superior Tribunal de Justiça, limitando a aplicação de medida de internação a ato infracional análogo ao crime de tráfico de entorpecentes: "O ato infracional análogo ao tráfico de drogas, 
por si só, não conduz obrigatoriamente à imposição de medida socioeducativa de internação do adolescente”.

Em relação ao segundo inciso do art. 122 da Lei $n^{\circ}$ 8.069/90, que se refere à reiteração no cometimento de outras infrações graves, desde há muito assentou a Corte Constitucional Brasileira que há necessidade, para fins de configuração da chamada 'reiteração', o cometimento anterior de pelos menos dois outros atos infracionais que tenham já sido reconhecidos em sentença transitada em julgado:

"Ato infracional: imposição de medida sócio-econômica de internação: ausência dos seus pressupostos (ECA, art. 122, I e II). 1. O regime da medida de internação pressupõe a tipicidade estrita das hipóteses legais que a autorizam. 2. A condenação imposta ao paciente, contudo, amolda-se à conduta descrita como tráfico de entorpecentes (L. 6.368/76, art. 12), na comissão do qual, no caso, não se utilizou de violência ou grave ameaça (art. 122, I, do ECA). 3. Também não configurada a hipótese do art. 122, II, do ECA: por "reiteração no cometimento de outras infrações graves”, à incidência da qual não é suficiente a mera existência de outros processos por fatos anteriores, mas a pré-existência de sentença transitada em julgado, reconhecendo a efetiva prática de pelo menos 2 duas infrações. 4 . Ademais, a "remissão não implica necessariamente o reconhecimento ou comprovação da responsabilidade, nem prevalece para efeito de antecedentes (...)" (ECA, art. 127). 5. Habeas corpus: deferimento para cassar a sentença, na parte em que impôs a medida de internação ao paciente, a fim de que outra seja aplicada. Extensão dos efeitos da decisão ao outro menor também condenado" (STF, 1a Turma, HC 88748/SP, j. em 14-10-2012).

Já no que tange à gravidade das infrações, a opção mais adequada é a sua verificação caso a caso, aquilatando-se as conse- 
quências do ato infracional efetivamente praticado (ROSSATO et. al.; 2011, p. 345).

Enfim, a última hipótese autorizadora de aplicação de medida de internação (e também semiliberdade) é o descumprimento reiterado e injustificado de medida anteriormente imposta (art. 122, III).

Neste caso, a restrição da liberdade não poderá exceder a três meses e deve ser judicialmente decretada após o devido processo legal (art. 122, § 1\%), no qual é imprescindível a oitiva prévia do reeducando, à luz do que dispõe o enunciado de número 265 da Súmula do Tribunal da Cidadania.

\subsection{Medidas de proteção aplicadas como medidas socioeducativas}

As medidas de proteção insertas no art. 101, I a VI, também podem ser aplicadas ao adolescente infrator, nos termos do art. 112, VII, do Estatuto da Criança e do Adolescente.

São elas: encaminhamento do adolescente aos pais ou responsável, mediante termo de responsabilidade; orientação, apoio e acompanhamento temporários; matrícula e freqüência obrigatórias em estabelecimento oficial de ensino fundamental; inclusão em programa comunitário ou oficial de auxílio à família, à criança e ao adolescente; requisição de tratamento médico, psicológico ou psiquiátrico, em regime hospitalar ou ambulatorial; e inclusão em programa oficial ou comunitário de auxílio, orientação e tratamento a alcoólatras e toxicômanos.

Saliente-se ser possível a cumulação de medidas protetivas com medidas socioeducativas não restritivas de liberdade sempre que a natureza de cada uma das medidas cumuladas forem compatíveis entre si (SARAIVA, 2002, p. 99).

Contudo, a cumulação das duas estirpes de medidas não é pacífica. A título de exemplo, cita-se que no Tribunal de Justiça do Rio Grande do Sul há quem não admita tal expediente ao argumento de que a medida socioeducativa em meio aberto 
deveria atender às necessidades dos adolescentes, o que tornaria desnecessária a aplicação de eventuais medidas protetivas (TJRS,

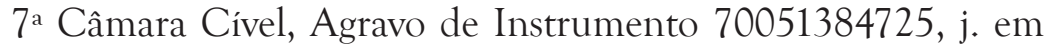
04-10-2012).

Alfim, há que se deixar claro que as medidas protetivas aplicadas em sede de persecução socioeducativa ostentam conteúdo fortemente pedagógico, porquanto são vocacionadas ao fortalecimento dos vínculos familiares e comunitários (SOTTO MAIOR, 2010, p. 537).

\section{PARÂMETROS NORMATIVOS DE APLICAÇÃO DAS MEDIDAS SOCIOEDUCATIVAS}

Consoante se defendeu no item dois deste artigo, o ponto fulcral do Direito Infracional é o resgate do adolescente infrator, redirecionando-o a um ambiente adequado e no qual seja respeitada sua condição de pessoa em estágio peculiar de desenvolvimento, com seus direitos mais essenciais eficazmente tutelados, inclusive para que com isso as chances de reincidir em condutas antijurídicas sejam minimizadas.

O meio fornecido pela Lei $\mathrm{n}^{\circ} 8.069 / 90$ para se atingir tal escopo é a aplicação, ao final de um processo de apuração de ato infracional, em que reconhecidas materialidade e autoria das imputações fáticas, de pelo menos uma das medidas socioeducativas previstas naquele diploma normativo, as quais já foram abordadas individualmente no tópico imediatamente anterior.

A eleição de qual das tais 'providências' socioeducativas é a mais adequada deve ser realizada, após análise minuciosa das nuances do caso concreto e dos parâmetros próprios do Direito Infracional, os quais estão normativamente previstos no Estatuto da Criança e do Adolescente.

Realmente, não se aventa a hipótese de se aplicar o método trifásico da dosimetria penal. Em primeiro lugar, porque as leis extravagantes que tutelam adolescentes - não só o Estatuto da Criança e do Adolescente, mas também a Lei do Sinase -, bem 
como a Constituição da República, têm princípios próprios para tanto.

Além disso, impraticável a sistemática do Código Penal porque, para cada crime ou contravenção a norma incriminadora já prevê de antemão uma pena, geralmente privativa de liberdade - mas que pode ser suspensa ou substituída - com limites específicos, face ao seu caráter precipuamente retributivo e preventivo, enquanto o Estatuto da Criança e do Adolescente prevê uma gama de medidas socioecudativas, a priori, passíveis de serem aplicadas a qualquer ato infracional, à exceção das restritivas de liberdade que, como visto, só podem ser aplicadas quando presente ao menos uma das hipóteses do art. 122 do mencionado Estatuto.

Nesse prisma, desponta a lição de Norberto de Almeida Carride:

"As medidas sócio-educativas têm por escopo também a emenda do infrator; são diferentes das penas, de maneira que não podem ser encaradas de forma idêntica. Por isso, a escolha da medida a ser aplicada pelo magistrado deve seguir critérios diferenciados daqueles contidos no Código Penal. A aplicação dos institutos penais e processuais penais (ECA: art. 152) pode ser feita, mas só subsidiariamente. Os objetivos do ECA são pedagógicos e ressocializantes. A norma prevê que o Juiz poderá aplicar uma das medida elencadas, de modo que se trata de uma faculdade e não obrigação. Ainda, em face do princípio da excepcionalidade (ECA: art. 121), todas as medidas mais brandas devem ser impostas ao adolescente antes de serem aplicadas as mais gravosas" (CARRIDE, 2006, p. 359).

Enfim, repise-se que os critérios utilizados pelo Direito Penal para aplicação de sanção são vocacionados para o escopo retributivo e muito focam no fato em si, ao passo que, o alvo principal da persecução socioeducativa deve recair sobre o adolescente infrator e os possíveis caminhos pelos quais se possa 
reconduzi-lo à plena fruição de seus direitos, respeitando-se a sua condição de pessoa em estágio peculiar de desenvolvimento.

Wilson Donizeti Liberati bem aquilata a diferenciação traçada:

"Por sua vez, o sistema de resposta estatal à prática de ato infracional, adotado pela Lei n. 8.069/1990, considera, primordialmente, a pessoa que o praticou, não estabelecendo vínculo desta ou daquela medida ao tipo penal praticado. Tal critério será de livre escolha do julgador, que fixará a medida socioeducativa mais adequada à socialização do infrator” (LIBERATI, 2006, p. 145).

Deste modo, rechaçada eventual apropriação dos critérios penais dosimétricos, passa-se a verificar os critérios próprios do Direito da Criança e do Adolescente, iniciando pelos insertos na Constituição da República, por questões de hierarquia normativa, e depois os previstos na legislação extravagante.

\subsection{Parâmetros constitucionais}

No capítulo VII do Título que regulamenta a Ordem Social, a Constituição da República Federativa do Brasil, ressaltando os direitos fundamentais da criança, do adolescente e do jovem, e albergando a Teoria da Proteção Integral, dispõe que a aplicação das medidas socioeducativas privativas de liberdade - semiliberdade e internação - devem obedecer aos princípios da brevidade e da excepcionalidade, bem como respeitar a condição peculiar de pessoa em desenvolvimento ${ }^{17}$.

17 "Art. 227. É dever da família, da sociedade e do Estado assegurar à criança, ao adolescente e ao jovem, com absoluta prioridade, o direito à vida, à saúde, à alimentação, à educação, ao lazer, à profissionalização, à cultura, à dignidade, ao respeito, à liberdade e à convivência familiar e comunitária, além de colocá-los a salvo de toda forma de negligência, discriminação, exploração, violência, crueldade e opressão. (...) $\S 3^{\circ}$ - O direito a proteção especial abrangerá os seguintes aspectos: (...) $\mathrm{V}$ - obediência aos princípios de brevidade, excepcionalidade e respeito à condição peculiar de pessoa em desenvolvimento, quando da aplicação de qualquer medida privativa da liberdade;" 
O Estatuto da Criança e do Adolescente, por sua vez, reproduz o comando constitucional ao disciplinar a medida de internação, cujos preceitos, como visto anteriormente, são também aplicáveis à semiliberdade: "Art. 121. A internação constitui medida privativa da liberdade, sujeita aos princípios de brevidade, excepcionalidade e respeito à condição peculiar de pessoa em desenvolvimento".

Os três parâmetros citados, malgrado sejam textualmente afetos às medidas de semiliberdade e de internação, são passíveis de serem aplicados, no que couber, quando da imposição das outras medidas previstas no Estatuto da Criança e do Adolescente.

A título de exemplo, pode-se dizer que não há muito sentido em se invocar a brevidade quanto à medida de advertência, já que ela consiste numa admoestação verbal imediata, mas é oportuna sua avaliação quando impostas, por exemplo, a liberdade assistida e/ou a prestação de serviços à comunidade.

Nessa esteira, quanto à duração das medidas socieducativas, o que se relaciona com a desejada brevidade, ensina Wilson Donizeti Liberati:

"Para sustentar o microssistema de individualização das medidas socioeducativas, o Estatuto estabelece a individualização das seguinte forma: a) duas medidas socioeducativas não têm termos de início e fim estabelecidos pela lei: a medida de Advertência é executada (...) em ato imediato à decisão, de forma verbal e a medida de Obrigação de reparar o dano, (...) também executada, de pronto, pelo juiz da sentença do processo de conhecimento; b) a medida de Prestação de Serviços à Comunidade consiste na realização de tarefas gratuitas de interesse geral (...) por prazo fixado em até seis meses, no máximo, cumpridas em jornadas de oito horas semanais (...); c) a medida de Liberdade Assistida (...) será fixada pelo prazo mínimo de seis meses, podendo a qualquer tempo ser prorrogada, revogada ou substituída 
por outra medida; d) as medidas de Inserção em Regime de Semiliberdade e de Internação, principais instrumentos de restrição de liberdade do jovem infrator, não comportam prazo determinado. Todavia, determina que sua manutenção deva ser reavaliada, no máximo a cada seis meses, sendo de três anos seu termo final, com liberação compulsória aos vinte e um anos de idade" (LIBERATI, 2006, p. 135-136).

Portanto, conclui-se que a aplicação de cada um de tais princípios varia, em maior ou menor grau, de acordo com as características de cada medida.

O SASC, o CONANDA e a UNICEF, em livreto a respeito do Sistema Nacional de Atendimento Socioeducativo, dá as seguintes orientações acerca dos referidos primados:

"Esses princípios são complementares e estão fundamentados na premissa de que o processo socioeducativo não se pode desenvolver em situação de isolamento do convívio social. Nesse sentido, toda medida socioeducativa, principalmente a privação de liberdade, deve ser aplicada somente quando for imprescindível, nos exatos limites da lei e pelo menor tempo possível, pois, por melhor que sejam as condições da medida socioeducativa, ela implica em limitação de direitos e sua pertinência e duração não deve ir além da responsabilização decorrente da decisão judicial que impôs" (SASC, 2006, p. 29).

Assim sendo, é possível dizer que, à luz do postulado da brevidade, a medida socioeducativa deve durar o mínimo possível e necessário à consecução das finalidades de sua aplicação, quais sejam, o resgate do adolescente e da integridade de seus direitos e ainda a conscientização quando aos efeitos de seus atos.

Também se coaduna com tal princípio a imediatidade da imposição da providência socioeducativa, pois quanto menor 
for o tempo entre a prática de ato infracional e o início da execução da medida socioeducativa, maior eficácia e utilidade ela terá (VALENTE, 2005, p. 28).

No que toca à excepcionalidade, é certo que as medidas menos graves devem ser adotadas, isolada ou cumulativamente, em preferência às mais gravosas (CARRIDE, 2006, p. 359).

Ainda nessa seara, é mister não olvidar que as mais graves de todas as medidas, as que privam a liberdade do adolescente, só podem ser aplicadas uma vez constadas as fattispecies do art. 122 da Lei no 8.069/90, e em casos agudos em que todas as demais medidas, aplicadas solitária ou cumulativamente, se mostrarem absolutamente ineficazes aos fins acima elencados.

Consagrando a excepcionalidade das medidas privativas de liberdade, cito excerto de julgado do Supremo Tribunal Federal, o guardião do texto constitucional:

"Estatuto da criança e do adolescente (ECA) - Interpretação. O ECA há de ser interpretado dando-se ênfase ao objetivo visado, ou seja, a proteção e a integração do menor no convívio familiar e comunitário, preservando-se-lhe, tanto quanto possível, a liberdade. ECA - Segregação. $O$ ato de segregação, projetando-se no tempo medida de internação do menor, surge excepcional, somente se fazendo alicerçado uma vez atendidos os requisitos do art. 121 da Lei 8.069/1990, não cabendo a indeterminação de prazo" (STF, HC 88.473/SP, j. em 03-06-2008).

Além nisso, como reforço argumentativo ao postulado da excepcionalidade, não se descura a redação do art. 45 da Lei do SINASE, mormente quando proíbe a imposição de medida de internação a adolescente que já cumpriram anteriormente medida da mesma natureza ou que tenha já sido transferido para um regime menos rigoroso de cumprimento de medida, situação em que os atos posteriores que ensejariam nova internação ficarão absorvidos por aqueles referentes à medida socioeducativa extrema já aplicada. 
O mencionado dispositivo, ao lado do art. 46, II, da Lei 12.584/12, que prevê a extinção da medida socioeducativa pela realização de sua finalidade, reforça a idéia da excepcionalidade na aplicação e na manutenção das medidas socioeducativas que cerceiam a liberdade do adolescente infrator.

Enfim, o respeito à condição peculiar de pessoa em desenvolvimento guarda relação com a idade do adolescente a quem se imporá alguma medida socioeducativa. Em outros dizeres, quanto menos tempo tiver passado desde que deixou de ser criança, menos graves hão de ser as medidas a ele aplicadas.

Eis a justificativa para a adoção de relevante parâmetro:

"Em nossa sociedade, a adolescência é considerada momento crucial do desenvolvimento humano, da constituição do sujeito em seu meio social e da construção de sua subjetividade. As relações sociais, culturais, históricas e econômicas da sociedade, estabelecidas dentro de um determinado contexto, são decisivas na constituição da adolescência. Portanto, para o pleno desenvolvimento das pessoas que se encontram nessa fase da vida é essencial que sejam fornecidas condições sociais adequadas à consecução de todos os direitos a elas atribuídos" (SASC, 2006, p. 27).

\subsection{Parâmetros do Estatuto da Criança e do Adolescente}

Além daqueles mencionados no tópico anterior, o Estatuto da Criança e do Adolescente ainda prevê, especificamente quanto à aplicação das medidas socioeducativas, outros critérios em seu art. 112, § 1०: "a capacidade do adolescente de cumpri-la, bem como as circunstâncias e a gravidade da infração”.

Acerca de tais balizadores, Olympio Sotto Maior esclarece:

"O § 10 do art. 112 estabelece, inicialmente, que a medida aplicada ao adolescente deve levar em conta sua capacidade de cumpri-la, ou seja, que apresente condições de exeqüi- 
bilidade. É que a imposição de medida irrealizável, além do inerente desprestígio à própria Justiça da Infância e da Juventude, acabaria reforçando juízo negativo (e formulado com freqüência pelos adolescentes) de incapacidade ou inaptidão para as coisas da vida, provocador de inevitável rebaixamento da autoestima. Ao invés de benefícios, a aplicação da medida traria prejuízos à formação da personalidade do adolescente. A parte final do parágrafo em tela, por outro lado, refere-se à necessária relação e proporcionalidade entre a medida aplicada e as circunstâncias e a gravidade da infração. A decisão desproporcionada ou que não guarde qualquer relação com o fato infracional praticado tenderá a perder contato com o processo educativo que lhe dá razão de existir, restando, nesse aspecto, inócua ou injusta” (SOTTO MAIOR, 2010, p. 537-538).

Realmente, a análise das circunstâncias e a gravidade do fato análogo a um delito que seja praticado por adolescente dão ao operador do Direito um norte quanto à extensão da necessidade de intervenção estatal socioeducativa para fins de recuperação do adolescente:

"Ao adolescente, a submissão a uma medida socioeducativa, para além de uma mera responsabilização, deve ser fundamentada não só no ato a ele atribuído, mas também no respeito à equidade (no sentido de dar o tratamento adequado e individualizado a cada adolescente a quem se atribua um ato infracional), bem como considerar as necessidades sociais, psicológicas e pedagógicas do adolescente. O objetivo da medida é possibilitar a inclusão social de modo mais célere possível e, principalmente, o seu pleno desenvolvimento como pessoa" (SASC, 2006, p. 30).

A capacidade de cumprimento da medida, por sua vez, também deve ser aferida caso a caso, de acordo com as características específicas, personalidade, ambiente familiar e história 
de vida do indivíduo que será submetido a uma das providências do art. 112 do Estatuto da Criança e do Adolescente.

Mas não se cingem a este dispositivo os princípios especificados pelo microssistema que tutela os que ainda não atingiram a maioridade sobre a aplicação das medidas socioeducativas.

Não se descura, nesse ponto, da literalidade do art. 100 da Lei $\mathrm{n}^{\circ} 8.069 / 90$, que regulamenta indistintamente a aplicação das medidas em geral - não só as protetivas, mas também as socioeducativas, por força do art. 113 - por ele disciplinadas:

Art. 100. Na aplicação das medidas levar-se-ão em conta as necessidades pedagógicas, preferindo-se aquelas que visem ao fortalecimento dos vínculos familiares e comunitários. Parágrafo único. São também princípios que regem a aplicação das medidas:

I - condição da criança e do adolescente como sujeitos de direitos: crianças e adolescentes são os titulares dos direitos previstos nesta e em outras Leis, bem como na Constituição Federal;

II - proteção integral e prioritária: a interpretação e aplicação de toda e qualquer norma contida nesta Lei deve ser voltada à proteção integral e prioritária dos direitos de que crianças e adolescentes são titulares;

III - responsabilidade primária e solidária do poder público: a plena efetivação dos direitos assegurados a crianças e a adolescentes por esta Lei e pela Constituição Federal, salvo nos casos por esta expressamente ressalvados, é de responsabilidade primária e solidária das 3 (três) esferas de governo, sem prejuízo da municipalização do atendimento e da possibilidade da execução de programas por entidades não governamentais;

IV - interesse superior da criança e do adolescente: a intervenção deve atender prioritariamente aos interesses e direitos da criança e do adolescente, sem prejuízo da 
consideração que for devida a outros interesses legítimos no âmbito da pluralidade dos interesses presentes no caso concreto;

$\mathrm{V}$ - privacidade: a promoção dos direitos e proteção da criança e do adolescente deve ser efetuada no respeito pela intimidade, direito à imagem e reserva da sua vida privada; VI - intervenção precoce: a intervenção das autoridades competentes deve ser efetuada logo que a situação de perigo seja conhecida;

VII - intervenção mínima: a intervenção deve ser exercida exclusivamente pelas autoridades e instituições cuja ação seja indispensável à efetiva promoção dos direitos e à proteção da criança e do adolescente;

VIII - proporcionalidade e atualidade: a intervenção deve ser a necessária e adequada à situação de perigo em que a criança ou o adolescente se encontram no momento em que a decisão é tomada;

IX - responsabilidade parental: a intervenção deve ser efetuada de modo que os pais assumam os seus deveres para com a criança e o adolescente;

$X$ - prevalência da família: na promoção de direitos e na proteção da criança e do adolescente deve ser dada prevalência às medidas que os mantenham ou reintegrem na sua família natural ou extensa ou, se isto não for possível, que promovam a sua integração em família substituta;

XI - obrigatoriedade da informação: a criança e o adolescente, respeitado seu estágio de desenvolvimento e capacidade de compreensão, seus pais ou responsável devem ser informados dos seus direitos, dos motivos que determinaram a intervenção e da forma como esta se processa; XII - oitiva obrigatória e participação: a criança e o adolescente, em separado ou na companhia dos pais, de responsável ou de pessoa por si indicada, bem como os seus pais 
ou responsável, têm direito a ser ouvidos e a participar nos atos e na definição da medida de promoção dos direitos e de proteção, sendo sua opinião devidamente considerada pela autoridade judiciária competente, observado o disposto nos $\S \S 1$ o e 20 do art. 28 desta Lei.

Quanto a esses preceitos insertos nos doze incisos do parágrafo único do artigo 100, é certo que se aplicam em maior ou menor amplitude na seara do Direito Infracional e, além disso, são autoexplicativos, dispensando maiores elucubrações.

Alguns, porém, por serem mais afetos à aplicação de medidas socioeducativas, merecem breves comentários.

Iniciando pelo caput, verifica-se que ressalta o viés pedagógico das medidas elencadas pelo Estatuto da Criança e do Adolescente, bem como privilegia as medidas que propiciem o fortalecimento dos vínculos familiares e comunitários, o que, em sede de medidas socioeducativas, predispõe a aplicação daquelas não privativas de liberdade, bem como privilegia a prevalência da família (inciso X), já que tais medidas implicam, total ou parcialmente, a retirada do adolescente de seu contexto familiar.

Realmente, a semilberdade e a internação só podem ser aplicadas se constatado o enquadramento do comportamento juvenil infracional em um dos incisos do art. 122 do Estatuto. Porém, a recíproca não é verdadeira, já que, verificada a ocorrência de uma das referidas hipóteses, não haverá que se aplicar necessariamente uma das duas medidas privativas de liberdade nominadas.

Ora, não é porque praticou um ato análogo a roubo, por exemplo, que deverá se submeter irresistivelmente à semiliberdade ou à internação (art. 122, I, do ECA). Tudo vai depender na análise dos motivos e das circunstâncias do ato infracional, e, notadamente, do histórico de vida, do contexto familiar e do grau de fruição que detinha dos direitos que lhe são constitucional e legalmente garantidos. 
Como na aplicação de qualquer das medidas com gênese no microssistema da infância e juventude, a viga mestra é a busca pela melhor medida que, diante da análise das nuances do caso concreto, será aquela proporcionalmente mais breve e eficaz (inc. VIII) na recondução do adolescente a um estado de respeito pleno de seus direitos, recuperando-o.

Noutros vocábulos, malgrado a Lei no $8.069 / 90$ preveja, por exemplo, a aplicação de medida de internação ou do regime de semiliberdade aos crimes cometidos com violência ou grave ameaça contra a pessoa, tem-se que tal diretriz não é rígida a ponto de obrigar o julgador, frente a ato infracional praticado mediante grave ameaça contra a pessoa, a aplicar somente uma das duas medidas privativas de liberdade insertas no Estatuto da Criança e do Adolescente.

Em verdade, repiso, a rigidez do artigo deve ser interpretada em sentido contrário. Explico: o que não se pode admitir é que atos infracionais que não sejam cometidos com violência ou grave ameaça contra a pessoa, ou que não preencham um dos dois outros requisitos alternativos do art. 122 da Lei $\mathrm{n}^{\circ}$ 8.069/90, deem ensejo à aplicação de medidas socioeducativas restritivas de liberdade - internação e semiliberdade.

Portanto, a presença de um dos requisitos alternativos do aludido dispositivo é condição indispensável à aplicação de medida socioeducativa privativa de liberdade, mas não impõe, por si só, a aplicação da internação ou do regime de semiliberdade, porquanto é possível, à luz das circunstâncias do caso concreto e das condições pessoais do adolescente, a imposição de medida socioeducativa menos gravosa, sempre que se mostrar mais adequada à boa formação da pessoa em estágio peculiar de desenvolvimento.

Trata-se de uma interpretação mais benéfica à pessoa em desenvolvimento, que se encontra em época peculiar de sua vida, e condizente com o sistema de proteção às crianças e adolescentes, que também privilegia a convivência familiar e social e a preservação dos direitos dos adolescentes. 
Além disso, é a opção que melhor se coaduna com o escopo principal da persecução socioeducativa, qual seja, ressocializar, reinserir o adolescente de forma saudável na família e na comunidade em que vive, melhorando seu bom relacionamento com os semelhantes, dando-lhe exemplos de respeito, mostrando-lhe os valores corretos a serem observados na sedimentação de sua personalidade.

De fato, reitero, apesar de inegáveis os objetivos retributivos do Direito Infracional, os olhos dos operadores jurídicos, nessa seara, quando da eleição de uma ou mais medidas socioeducativas, devem se voltar principalmente ao melhor interesse da pessoa em desenvolvimento, ao resgate do adolescente infrator com sua consequente reinserção em ambiente favorável ao seu sadio crescimento.

No que toca ao postulado da condição da criança e do adolescente como sujeitos de direitos (inciso I), não se pode perder de vista o fato de que, como pessoas, os que não completaram dezoito anos são credores de prestações positivas por parte do Estado, da sociedade e da família e, além de compartilhar dos mesmos direitos dos adultos, ainda desfrutam de alguns que lhes são próprios, como o próprio direito de brincar (ROSSATO et. al.; 2011, p. 81). Na seara do Direito Infracional, ainda detêm garantias processuais peculiares, nos termos dos arts. 110 e 111 da Lei no 8.069/90".

Outro princípio que merece destaque é o da intervenção precoce (inciso VI), através do qual as providências tomadas pelo poder público devem ocorrem o mais cedo possível, para que o adolescente tenha seus direitos restabelecidos o quanto antes, sendo devolvido a um curso sadio de desenvolvimento pessoal, social e familiar.

Assim, a intervenção precoce, em termos de aplicação de medidas socioeducativas, relaciona-se com as premissas da proporcionalidade e da atualidade (inciso VIII), as quais comandam que a atuação estatal deve ser o máximo possível contemporânea à época do ato análogo a crime ou contravenção penal. 
Portanto, caso não seja ao adolescente concedida remissão, o procedimento de apuração de ato infracional deve ser célere a ponto de corresponder a uma rápida medida que pelo adolescente possa ser relacionada com a prática antijurídica, potencializando os efeitos pedagógicos da medida socioeducativa eventualmente infligida.

Especificamente quanto à proporcionalidade, a medida eleita deve guardar proporção com a gravidade do fato (CARRIDE, 2006, p. 313), no sentido de não se aplicar aquelas que sejam graves a condutas menos significativas e, além disso, ser aquela que mais se mostre necessária e adequada à recuperação do adolescente (ROSSATO et. al.; 2011, p. 82), não aniquilando direitos seus.

Por fim, não se pode deixar de mencionar o interesse superior da criança e do adolescente que, nas palavras de Eduardo Rezende de Melo, tem natureza de garantia:

"Ele limita as faculdades do Estado para intervir nos assuntos relacionados à infância e à adolescência, impondo-lhes, ao mesmo tempo, obrigações, tomando o superior interesse da crianca como uma consideração primordial no exercício de suas atribuições, na mesma medida em que crianças e adolescentes têm direitos que devem ser respeitados e promovidos. Neste sentido, o princípio assume o caráter de verdadeira garantia, isto é, vínculo normativo idôneo para assegurar a efetividade dos direitos subjetivos. Como princípio garantista, o interesse superior significa fundamentalmente a satisfação dos direitos de crianças e adolescentes" (MELO, 2010, p. 426).

Deste modo, o princípio em tela reafirma o escopo do resgate dos direitos do adolescente mediante aplicação de medida socioeducativa apta a reconduzi-lo a um contexto familiar saudável e apto ao seu bom desenvolvimento. 


\subsection{Parâmetros previstos na Lei do SINASE}

A Lei no 12.594/2012, que instituiu o Sistema Nacional de Atendimento Socioeducativo - SINASE, regulamenta a execução das medidas impostas a adolescente que comprovadamente tenha praticado ato análogo a crime ou contravenção penal.

Para Alexandre Morais da Rosa, "O SINASE, apesar de não ter expresso em sua denominação, configura-se em um 'Plano', no qual as ações objetivam o atendimento condizente para adequação aos seus direitos dos adolescentes autores de atos infracionais" (ROSA et al, 2011, p. 348).

A lei extravagante em tela traz, em seu art. 35, algumas balizas para o intérprete em sua atividade de aplicação de medidas socioeducativas, textualmente nominando-as de 'princípios':

"Art. 35. A execução das medidas socioeducativas reger-se-á pelos seguintes princípios:

I - legalidade, não podendo o adolescente receber tratamento mais gravoso do que o conferido ao adulto;

II - excepcionalidade da intervenção judicial e da imposição de medidas, favorecendo-se meios de autocomposição de conflitos;

III - prioridade a práticas ou medidas que sejam restaurativas e, sempre que possível, atendam às necessidades das vítimas;

IV - proporcionalidade em relação à ofensa cometida;

$\mathrm{V}$ - brevidade da medida em resposta ao ato cometido, em especial o respeito ao que dispõe o art. 122 da Lei no 8.069, de 13 de julho de 1990 (Estatuto da Criança e do Adolescente);

VI - individualização, considerando-se a idade, capacidades e circunstâncias pessoais do adolescente;

VII - mínima intervenção, restrita ao necessário para a realização dos objetivos da medida; 
VIII - não discriminação do adolescente, notadamente em razão de etnia, gênero, nacionalidade, classe social, orientação religiosa, política ou sexual, ou associação ou pertencimento a qualquer minoria ou status; e

IX - fortalecimento dos vínculos familiares e comunitários no processo socioeducativo".

Muitos dos parâmetros previstos no supracitado artigo são também literalmente previstos pelo Estatuto da Criança e do Adolescente (incisos II, IV, V, VII e IX). Foram eles abordados, direta ou indiretamente, no tópico anterior (art. 100, caput, e seu parágrafo único, incisos VI, VII, VIII e X, do ECA) e, por isso, agora o foco passa aos remanescentes.

A função do princípio da legalidade no processo de execução de medida socioeducativa é explicada com propriedade por Wilson Donizeti Liberati:

"A regra da legalidade na execução tem como objetivo, primordialmente, impedir que os excessos ou desvios de sua finalidade afetem a dignidade e a humanidade do infrator. Em outras palavras, a Administração Pública e os órgãos jurisdicionais deverão aplicar a lei, segundo seus precisos comandos, vetada a criação de novos direitos ou obrigações, importando sua efetividade nas regras sobre as modalidades de execução das inflições impostas" (LIBERATI, 2006, p. 152).

Por sua vez, a desejada preponderância das práticas restaurativas reflete antes de tudo a preponderância do cunho ressocializador ao escopo retributivo das medidas socioeducativas, já que privilegia o atendimento às necessidades das vítimas, na medida do possível, bem como se constitui em uma forma de conscientizar o adolescente das consequências que seus atos podem ocasionar para os demais indivíduos da sociedade onde entrega.

O comando da individualização da medida socioeducativa à luz da idade, capacidade e circunstâncias pessoais do adoles- 
cente demonstra a preocupação dos instrumentos normativos que regulamentam a aplicação e execução de medidas socioeducativas com a pessoa em peculiar estágio de desenvolvimento, almejando sua reestruturação social, psicológica e familiar.

A proibição de discriminação do adolescente é um consectário dos direitos constitucionalmente previstos da igualdade e da não discriminação (arts 3, IV, e $5^{\circ}$, caput, e seus incisos I e XLI).

O citado princípio tem dado respaldo para que o operador jurídico assegure que o adolescente tenha, no mínimo, um tratamento processual que lhe confira as mesmas garantias atribuídas aos imputáveis, além daquelas que lhe são próprias, insertas no Estatuto da Criança e do Adolescente, e que se justificam em sua condição de pessoa em peculiar estágio de desenvolvimento.

Alfim, ainda há mencionar o teor do art. 42, § 2०, da Lei do SINASE: "Art. 42 (...) § 2० A gravidade do ato infracional, os antecedentes e o tempo de duração da medida não são fatores que, por si, justifiquem a não substituição da medida por outra menos grave".

Trata-se de uma proibição de utilização isolada dos parâmetros nele elencados, sem o amparo de demais argumentos razoáveis, para fins de se obstar a substituição de uma medida que está sendo executada por outra mais benéfica.

Apesar de se tratar de um dispositivo com aplicação textualmente afeta ao momento da execução de medidas socioeducativas, não há óbice para que sejam balizadores do julgador quando, no ato final do processo de apuração de ato infracional, aplicar ao adolescente uma ou mais medidas socioeducativas.

\section{CONCLUSÃO}

O Estatuto da Criança e do Adolescente não prevê, como o faz o Direito Penal, um sistema de critérios legais que de antemão fixe qual a medida socioeducativa abstratamente aplicável a cada ato análogo a crime ou contravenção, e nem esti- 
pula patamares mínimos e máximos de tempo de cumprimento de medidas socioeducativas para cada fato típico.

Destarte, a aplicação de medidas socioeducativas implica necessariamente numa atividade hermenêutica em que o magistrado detém maior discricionariedade para eleger qual(is) da(s) medida(s) socioeducativa(s) são mais adequadas a cada caso concreto.

A referida atividade jurisdicional, contudo, não é arbitrária, uma vez que o magistrado deve observar os parâmetros normativos afetos ao Direito Infracional.

Há critérios insertos na Constituição da República e na legislação extravagante, estes previstos não só na Lei no 8.069/90 - Estatuto da Criança e do Adolescente - como também na Lei no 12.594/2012 - a Lei do SINASE.

No conjunto de todos os princípios norteadores da eleição de medidas socioeducativas, há alguns de caráter geral, que se aplicam indistintamente a qualquer medida, como a proporcionalidade, e também outros que, apesar de serem originalmente, pela letra da lei, vocacionados a medidas específicas, como a brevidade, podem ser, em maior ou menor grau, utilizados na eleição de todas as medidas, quando não contraste com a natureza de cada qual.

Desta forma, o operador jurídico, ao eleger qual ou quais das medidas socioeducativas serão impostas ao adolescente infrator que comprovadamente tenha cometido ato análogo a crime ou contravenção, deve procurar sopesar todos os postulados aqui expostos, para então obter um resultado mais fidedigno com os escopos da persecução socioeducativa.

E é justamente este o ponto central que deve guiar o magistrado durante toda a atividade jurisdicional relativa ao Direito Infracional, não só no desenrolar processual mas, acima de tudo, no ato final do processo de apuração de ato infracional, a sentença que, caso condenatória, determinará a submissão do adolescente a uma medida socioeducativa.

Conclui-se, assim, que a utilização de cada um dos postulados, dos balizadores abordados neste estudo, deve se pautar 
pela constante busca da concretização dos escopos da persecução socioeducativa, calcada na Teoria da Proteção Integral, os quais correspondem, essencialmente, à recuperação do adolescente infrator sob o viés pedagógico e à sua reinserção em um ambiente propício ao seu sadio crescimento físico e psíquico, onde seus direitos fundamentais sejam resgatados e seja respeitada sua condição de pessoa em estágio peculiar de desenvolvimento, escopos estes que a que se deve conferir preponderância em relação aos fins outros do Direito Infracional, nomeadamente os retributivos e punitivos.

\begin{abstract}
Addresses the legal criteria for application of socio-educational measures to adolescent delinquents. Emphasizes the pedagogical objectives of the socioeducative prosecution. It covers the characteristics of each socio-educational measures that integrate the exhaustive list of art. 112 of the Statute of Children and Adolescents. Intends to provide parameters for the election of educative measures more appropriate in each case, since the rules governing the right offense not prefix specific measures for each of the types infraction, similar to criminal offenses or misdemeanors.
\end{abstract}

Keywords: socio-educational measures. Criteria of application.

\title{
REFERÊNCIAS
}

BRASIL. Código de menores. Lei 6.697, de 10 de outubro de 1979. Código de Menores. Disponível em <http://www.planalto.gov.br>. Acesso em 21/10/2012. . Constituição (1988). Constituição da República Federativa do Brasil. Disponivel em <http://www.planalto.gov.br >. Acesso em 21/10/2012.

. Estatuto da Criança e do Adolescente. Lei n. 8.069, de 13 de julho de 1990. Estatuto a Criança e do Adolescente. Disponível em <http:// www.planalto.gov.br>. Acesso em 13/10/2012. 
. Lei do SINASE. Lei n. 12.594, de 18 de janeiro de 2012. Lei do Sistema Nacional de Atendimento Socioeducativo. Disponível em <http://www. planalto.gov.br>. Acesso em 21/10/2012.

. Tribunal de Justiça do Rio Grande do Sul, Sétima Câmara Cível, Agravo de Instrumento 70051384725. Rel. Liselena Schifino Robles Ribeiro, j. em 04/10/2012. Disponível em <www.tjrs.jus.br>, acesso em 15-12-2012.

. Superior Tribunal de Justiça, Plenário, enunciado 265 da Súmula. Publicada no DJe em 29-05-2002. Disponível em <www.sjt.jus.br>, acesso em 14-10-2012.

enunciado 338 da Súmula.

Publicada no DJe em 16-05-2007. Disponível em <www.sjt.jus.br>, acesso em 21-10-2012.

, enunciado 492 da Súmula.

Publicada no DJe em 13-08-2012. Disponível em 〈www.sjt.jus.br〉, acesso em 14-10-2012.

Quinta Turma, HC 155.514/SP,

Rel. Min. Arnaldo Esteves Lima, j. em 15-06-2010. Disponível em <www.stj. jus.br>, acesso em 29-10-2012.

. Supremo Tribunal Federal, $1^{\text {a }}$ Turma, HC 88748/SP. Rel. Min. Sepúlveda Pertence, j. em 08-08-2006. Disponível em <www.stf.jus.br>, acesso em 14-10-2012.

. Supremo Tribunal Federal, 1a Turma, HC 88.473/SP. Rel. Min. Marco Aurélio, j. em 3-6-2008, DJE de 5-9-2008. Disponível em <www.stf. jus.br>. Acesso em 24-10-2012.

CARRIDE, Norberto de Almeida. Estatuto da Criança e do Adolescente Anotado. Campinas: Servanda Editora, 2006.

COSTA, Ana Paula Motta. As garantias processuais e o Direito Penal Juvenil como limite na aplicação da medida socioeducativa de internação. Porto Alegre: Livraria do Advogado Editora, 2005.

CURY, Munir (coord.). Estatuto da Criança e do Adolescente Comentado: comentários jurídicos e sociais. 11. ed. São Paulo: Malheiros Editores, 2010.

D'ANDREA, Giuliano. Noções de Direito da Criança e do Adolescente.

Florianópolis: OAB/SC Editora, 2005.

ELIAS, Roberto João. Direitos fundamentais da criança e do adolescente. São Paulo: Saraiva, 2005. 
ILANUD; ABMP; SEDH; UNFPA (orgs.). Justiça, Adolescente e Ato Infracional: socialização e responsabilização. São Paulo: ILANUD, 2006.

ISHIDA, Válter Kenji. Estatuto da Criança e do Adolescente: doutrina e jurisprudência. 12. ed. São Paulo: Atlas, 2010.

LIBERATI, Wilson Donizeti. Comentários ao Estatuto da Criança e do Adolescente. 9. ed. rev. e ampl. São Paulo: Malheiros Editores, 2006. - Processo penal juvenil: a garantia da legalidade na execução da medida socioeducativa. São Paulo: Malheiros Editores, 2006.

PAULA, Paulo Afonso Garrido de. Direito da Criança e do Adolescente e tutela jurisdicional diferenciada. São Paulo: Editora Revista dos Tribunais, 2002.

RAMIDOFF, Mário Luiz. Lições de Direito da Criança e do Adolescente: ato infracional e medidas socioeducativas. 2. ed. rev. e atual. Curitiba: Juruá, 2008.

ROSA, Alexandre Morais da; LOPES, Ana Christina Brito. Introdução crítica ao ato infracional: princípios e garantias constitucionais. Rio de janeiro: Lumen Juris, 2011.

ROSSATO, Luciano Alves; LÉPORE, Paulo Eduardo; CUNHA, Rogério Sanches. Estatuto da Criança e do Adolescente comentado. 2. ed. rev., atual, e ampl. São Paulo: Editora Revista dos Tribunais, 2011.

SARAIVA, João Batista Costa. Direito Penal Juvenil: adolescente e ato infracional: garantias processuais e medidas socioeducativas. 2. ed. rev. e ampl. Porto Alegre: Livraria do Advogado Editora, 2002.

- O Adolescente em Conflito com a Lei e sua Responsabilidade: Nem abolicionismo penal, nem direito penal máximo. p. 11-12. Disponível em <http://www.jbsaraiva.blog.br/blog/wp-content/ uploads/2008/07/adolescente2.pdf $>$, acesso em 15-12-2012.

SASC; CONANDA; UNICEF. SINASE: Sistema Nacional de Atendimento Socioeducativo. Brasília, junho de 2006.

VALENTE, José Jacob. Estatuto da Criança e do Adolescente: apuração de ato infracional à luz da jurisprudência: Lei Federal no 8.069, de 13-7-1990. 2. ed. São Paulo: Atlas, 2005.

VERONESE, Josiane Rose Petry. Medidas sócio-educativas: sinônimo de Pena?. In: Âmbito Jurídico, Rio Grande, XI, n. 57, set 2008. Disponível em: <http://www.ambito-juridico.com.br/site/index.php?n_link=revista_ artigos_leitura\&artigo_id=5164>. Acesso em 15-12-2012. 